\title{
Synthesis and Characterization of Precursors for Group II Metal Aluminates
}

\author{
Ramasubramanian Narayanan* and Richard M. Laine* \\ Department of Materials Science and Engineering and Department of Chemistry, 2510, G. G. Brown, \\ 2300, Hayward Ave, University of Michigan, Ann Arbor, MI 48109-2136, USA
}

\begin{abstract}
Precursors to Group II metal aluminates $\left(\mathrm{MAI}_{2} \mathrm{O}_{4}, \mathrm{M}=\mathrm{Mg}, \mathrm{Ca}, \mathrm{Ba}, \mathrm{Sr}\right)$ are synthesized from inexpensive starting materials including Group II metal oxides/hydroxides, $\mathrm{Al}(\mathrm{OH})_{3}$, triethanolamine (TEA) and ethylene glycol, in a one-pot synthesis process. The precursors are soluble in common organic solvents and can be handled in moist air for a reasonable period of time. On pyrolysis in air to $1200{ }^{\circ} \mathrm{C}$, all three precursors transform to the corresponding Group II metal aluminates. A termetallic double alkoxide, 'ionomer-like' structure is proposed, wherein the alkalineearth metal is encapsulated by a TEA molecule bridging two alumatrane units. The precursors were characterized using TGA, NMR, mass spectroscopy and elemental analyses, and the pyrolysed precursors were briefly characterized using $x$-ray diffraction analysis. () 1997 John Wiley \& Sons, Ltd.
\end{abstract}

Appl. Organometal. Chem. 11, 919-927 (1997)

No. of Figures: 4 No. of Tables: 3 No. of Refs: 26

Keywords: double alkoxides; precursors; Group II metal aluminates

Received 11 March 1997; accepted 30 June 1997

\section{INTRODUCTION}

Chemical synthesis has become an indispensable tool in processing mixed-cation oxide ceramics, especially as newer applications typically require

* Correspondence to: Ramasubramanian Narayanan, Departments of Materials Science and Engineering and Department of Chemistry, 2510, G. G. Brown, 2300, Hayward Ave, University of Michigan, Ann Arbor, MI 48109-2136, USA.

Contract grant sponsor: Federal Aviation Administration; Contract grant number: $95-\mathrm{G}-026$.

Contract grant sponsor: Army Research Office; Contract grant no. DAAH04-95-1-0407. greater purity and better control over product properties. The Group II metal aluminates $\left(\mathrm{MAl}_{2} \mathrm{O}_{4}, \mathrm{M}=\mathrm{Mg}, \mathrm{Ca}, \mathrm{Ba}, \mathrm{Sr}\right.$ ) are one important class of mixed-cation oxide ceramics with widespread applications. For example, $\mathrm{CaAl}_{2} \mathrm{O}_{4}$ is used as a hydraulic material in the cement industry ${ }^{1}$ and also in high-strength, high-toughness ceramic/polymer composite materials. ${ }^{2}$ Spinel $\left(\mathrm{MgAl}_{2} \mathrm{O}_{4}\right)$ is used as a refractory and insulating material. ${ }^{3,4}$ Strontium and barium aluminates are used as catalyst supports ${ }^{5}$ and they make good luminophores when doped with appropriate transition-metal ions. ${ }^{6}$ The availability of homogeneous, chemically and phase-pure, high surface area materials is crucial for most if not all of these applications.

Conventional synthesis of ceramic materials by solid-state reactions which involve reaction of individual oxides or carbonates at high temperatures $\left(>1400{ }^{\circ} \mathrm{C}\right)^{7}$ are inefficient, especially in the case of mixed-cation oxide ceramics, as they often lead to inhomogeneous products with imprecise control over product stoichiometry and phase purity. Although chemical synthesis routes overcome these problems and offer access to processable precursors and homogeneous ceramic materials, they are still plagued by certain problems. For example, sol-gel processing, the most widely used chemical processing route, requires hydrolytically unstable and expensive metal alkoxides. ${ }^{8}$ Other chemical approaches, such as freeze-drying, co-precipitation etc., involve cumbersome processing techniques. ${ }^{9}$

To date, the Pechini process, which involves polyesterification of citric acid metal chelates with ethylene glycol (EG) and subsequent pyrolysis of the resultant resinous intermediate, offers the most efficient, economical and general method for the synthesis of multimetallic oxides. $^{10}$ A variety of mixed-metal oxides, including calcium aluminate, can be prepared by the Pechini process and its modifications, e.g. the 'liquid-mix' process. ${ }^{11}$ However, the final mor- 
phology of the ceramic material depends on a number of factors, including: the order of addition of reagents; the $\mathrm{H}_{2} \mathrm{O}$ /citric acid/EG ratio; the heating schedule during gelation and calcination; and the mass ratio of polymeric resin to the metal. ${ }^{10,12}$ The chemistry of the starting precursor solution and that of intermediate species in Pechini processes have been studied in a few systems, ${ }^{12-14}$ but not for aluminate precursors.

A few alternative chemical routes to Group II metal aluminates have been reported, but the precursor chemistry is not discussed to any extent. ${ }^{15-17}$ The rational synthesis of materials via chemical routes requires an understanding of the structure and chemistry of the precursors, so that the process can be generalized.

We recently reported a general, low-cost route to alkoxide precursors to mixed-cation oxide ceramics (spinel, mullite and cordierite), by direct reaction of any stoichiometric mixture of $\mathrm{SiO}_{2}, \mathrm{Al}(\mathrm{OH})_{3}$ and Group I/II metal hydroxides with EG and triethanolamine (TEA). ${ }^{18}$ This route, termed the 'oxide one-pot synthesis' (OOPS) process, provides stable processable precursors to a wide variety of phase-pure and selectively doped ceramics. It uses simple, inexpensive starting materials that make it more economical than the Pechini process, where metal nitrates can account for $60-80 \%$ of the total cost. ${ }^{10}$ Of the various OOPS precursors synthesized to date, molecular structures have been described only for the spinel $\left(\mathrm{MgAl}_{2} \mathrm{O}_{4}\right)$ and potassium aluminosilicate $\left(\mathrm{K}_{2} \mathrm{O} \cdot \mathrm{Al}_{2} \mathrm{O}_{3}-\right.$ - $2 \mathrm{SiO}_{2}$ ) precursors. ${ }^{19,20}$ Herein we extend the efforts to other Group II metal aluminates.

A general reaction for the synthesis of OOPSderived precursors is given by Eqn [1].

$$
\begin{aligned}
& x \mathrm{MOH}+y \mathrm{SiO}_{2}+z \mathrm{Al}(\mathrm{OH})_{3}+(x+y+z) \mathrm{TEA} \\
& \stackrel{200^{\circ} \mathrm{C} / \text { excess EG } / 5-10 \mathrm{~h}}{\longrightarrow} \mathrm{M}_{x} \mathrm{Si}_{y} \mathrm{Al}_{z}(\mathrm{TEA})_{x+y+z}
\end{aligned}
$$

The OOPS synthesis of the magnesium aluminate (spinel) precursor is shown in Eqn [2]. The
$2 \mathrm{Al}(\mathrm{OH})_{3}+3 \mathrm{~N}\left(\mathrm{CH}_{2} \mathrm{CH}_{2} \mathrm{OH}\right)_{3}+\mathrm{Mg}(\mathrm{OH})_{2}$

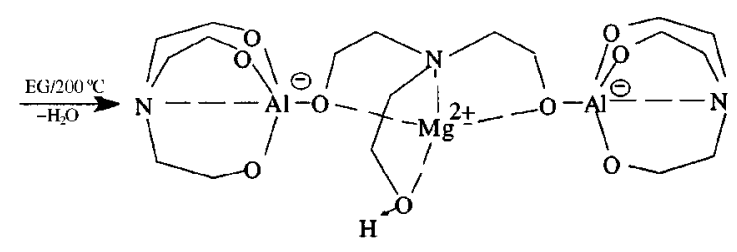

[2]

spinel precursor can also be made stepwise via an alumatrane $\left[(\mathrm{TEAAl})_{4}\right]$ intermediate. ${ }^{19}$ In the present study the precursors are made stepwise, via a variation on the OOPS process according to the reactions represented by Eqns [3] and [4], so that the intermediates and precursors can be characterized. It is shown that the OOPS process leads to similar precursors.

\section{EXPERIMENTAL}

\section{General synthesis procedures}

All operations were carried out with careful exclusion of extraneous moisture. Air- and moisture-sensitive materials were handled using standard Schlenk techniques in a nitrogen atmosphere in a Vacuum Atmospheres MO40-2-Dri-Lab glovebox (Vacuum Atmospheres Co., Hawthorne, CA, USA). All chemicals were reagent-grade, purchased from standard vendors and used as received unless otherwise specified. Ethylene glycol (EG) (AR,

$$
\mathrm{Al}(\mathrm{OH})_{3}+\mathrm{N}\left(\mathrm{CH}_{2} \mathrm{CH}_{2} \mathrm{OH}\right)_{3}
$$

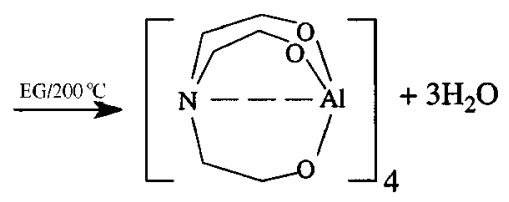

[3]

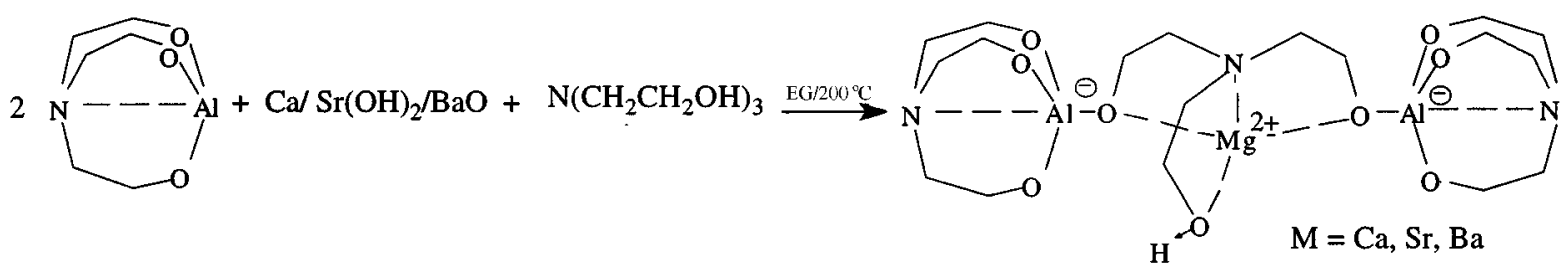


Baker) was used as received. Recovered EG was distilled twice and recycled.

\section{Stepwise syntheses}

Syntheses of alumatrane from $\mathrm{Al}(\mathrm{OH})_{3}$, and from it the spinel precursor, are described elsewhere. ${ }^{19}$ Syntheses of other Group II metal aluminate precursors from alumatrane are described below. NMR, mass spectroscopy and elemental analyses data for the precursors are tabulated in the Results and discussion section.

\section{Calcium aluminate precursor}

$\left(\mathrm{CaAl}_{2} \mathrm{C}_{18} \mathrm{H}_{37} \mathrm{O}_{\mathbf{9}} \mathbf{N}_{3}\right)$

Calcium $(0.92 \mathrm{~g}, 23.0 \mathrm{mmol})$ was dissolved in approx. $100 \mathrm{~mL}$ of EG by refluxing for about $10 \mathrm{~h}$. A solution of (TEAAl) $)_{4}$ (ceramic yield $=28.8 \%, 7.98 \mathrm{~g}, 23.0 \mathrm{mmol}$ ) and triethanolamine (TEA) $(3.43 \mathrm{~g}, 23.0 \mathrm{mmol})$ in $100 \mathrm{ml}$ of EG was added to the calcium solution. The reaction mixture was stirred and heated to distill off EG. The reaction mixture cleared on heating and after about an hour the solution was concentrated to $100 \mathrm{ml}$. The remaining solvent was removed by heating under vacuum at $170{ }^{\circ} \mathrm{C}$ for $12 \mathrm{~h}$. The resultant light-brown solid was crushed under nitrogen and vacuum-dried at $200{ }^{\circ} \mathrm{C}$ for $6 \mathrm{~h}$. Yield: $11.3 \mathrm{~g}(91.9 \%)$. The TGA ceramic yield of the solid is $28.9 \%\left(1000{ }^{\circ} \mathrm{C}\right.$ in air). Theoretical ceramic yield calculated for the formation of $\mathrm{CaAl}_{2} \mathrm{O}_{4}$ from the proposed precursor: 29.6\%. Elemental analyst (\%): Found (calculated): C, 40.5 (40.5); H, 7.1 (6.9); N, 7.6 (7.9).

\section{Strontium aluminate precursor \\ $\left(\mathrm{SrAl}_{\mathbf{2}} \mathrm{C}_{\mathbf{1 8}} \mathrm{H}_{37} \mathrm{O}_{\mathbf{9}} \mathbf{N}_{\mathbf{3}}\right)$}

$\mathrm{Sr}(\mathrm{OH})_{2} .8 \mathrm{H}_{2} \mathrm{O} \quad(10.0 \mathrm{~g}, 37.7 \mathrm{mmol})$ was dissolved in $200 \mathrm{ml}$ of EG by heating in a $500 \mathrm{ml}$ Schlenk flask. $\left(\right.$ TEAAl) ${ }_{4}$ (ceramic yield $=28.8 \%$, $14.0 \mathrm{~g}, 79.2 \mathrm{mmol})$ along with TEA $(5.62 \mathrm{~g}$, $37.7 \mathrm{mmol}$ ), dissolved in $60 \mathrm{ml}$ of EG, was then added. The resultant solution was heated to $200{ }^{\circ} \mathrm{C}$ to distil off EG. The reaction mixture cleared on heating and after about two hours the solution was concentrated to $100 \mathrm{ml}$. The resultant viscous solution was vacuum-dried at $180{ }^{\circ} \mathrm{C}$ for $12 \mathrm{~h}$ to yield a light-brown solid. Yield: $21.3 \mathrm{~g}$ (97.2\%). The solid was dissolved in THF, reprecipitated in hexane, vacuum-dried at $100{ }^{\circ} \mathrm{C}$ for $6 \mathrm{~h}$ and then subjected to analyses.
The TGA ceramic yield of the resultant solid was $35.2 \%\left(1000{ }^{\circ} \mathrm{C}\right.$ in air). Theoretical ceramic yield calculated for the formation of $\mathrm{SrAl}_{2} \mathrm{O}_{4}$ from the proposed precursor: $35.4 \%$. Elemental analysis (\%): Found (calculated): C-, 36.1 (37.2); $\mathrm{H}, 6.5$ (6.4); N, 6.6 (7.2).

\section{Barium aluminate precursor}

$\left(\mathrm{BaAl}_{2} \mathbf{C}_{18} \mathbf{H}_{37} \mathbf{O}_{9} \mathbf{N}_{3}\right)$

$\mathrm{BaO}(8.0 \mathrm{~g}, 52.3 \mathrm{mmol})$ was weighed and mixed with $150 \mathrm{ml}$ of degassed EG in a $250 \mathrm{ml}$ Schlenk flask, in the drybox. The mixture was taken out of the drybox and heated under nitrogen to obtain a cloudy viscous solution. A solution of $(\text { TEAAl })_{4} \quad$ (ceramic yield $=28.8 \%, \quad 18.6 \mathrm{~g}$, $105 \mathrm{mmol}$ of $\left.\mathrm{Al}_{2} \mathrm{O}_{3}\right)$ in approx. $60 \mathrm{ml}$ of EG and TEA $(7.80 \mathrm{~g}, 52.3 \mathrm{mmol})$ were then added to the $\mathrm{BaO}$ solution. The reaction mixture was stirred and heated to distil off EG. The reaction mixture did not become clear, and a solid precipitated out within $10 \mathrm{~min}$ after the two solutions were mixed. The reaction mixture was vacuum-dried at $180{ }^{\circ} \mathrm{C}$ for $6 \mathrm{~h}$. The solid that formed was crushed under nitrogen and further vacuum-dried at $180{ }^{\circ} \mathrm{C}$ for $12 \mathrm{~h}$. Yield: $30.8 \mathrm{~g}(92.5 \%)$. The TGA ceramic yield of the solid is $40.1 \%$ $\left(1000{ }^{\circ} \mathrm{C}\right.$ in air). Theoretical ceramic yield calculated for the formation of $\mathrm{BaAl}_{2} \mathrm{O}_{4}$ from the proposed precursor: $40.5 \%$. Elemental analysis (\%): Found (calculated): C, 33.3 (34.2); H, 5.7 (5.9); N, 5.6 (6.6). The results of the elemental analysis are outside the acceptable range, probably due to the precipitation that occurred during the synthesis as a result of the low solubility of the barium aluminate precursor, as discussed in the Results and discussion section.

\section{OOPS syntheses}

\section{Calcium aluminate precursor}

\section{$\left(\mathrm{CaAl}_{2} \mathrm{C}_{18} \mathrm{H}_{37} \mathrm{O}_{9} \mathrm{~N}_{3}\right)$}

Aluminium hydroxide hydrate $(6.61 \mathrm{~g}$, $35.8 \mathrm{mmol}$ of $\left.\mathrm{Al}_{2} \mathrm{O}_{3}\right)$, and $\mathrm{CaO}(2.01 \mathrm{~g}$, $35.9 \mathrm{mmol})$ were mixed with TEA $(16.1 \mathrm{~g}$, $108 \mathrm{mmol}, 1$ nitrogen per metal atom) in $200 \mathrm{ml}$ of EG in a $250 \mathrm{ml}$ flask. The solution was heated and EG was distilled off along with the $\mathrm{H}_{2} \mathrm{O}$ formed. The solution cleared in about $30 \mathrm{~min}$ during heating. The solution was concentrated to $50 \mathrm{ml}$ and the remaining solvent was vacuumdried at $150{ }^{\circ} \mathrm{C}$ for $12 \mathrm{~h}$. The resultant light-yellow solid weighed $17.7 \mathrm{~g}(92.9 \%)$ and had a TGA ceramic yield of $26.5 \%\left(950{ }^{\circ} \mathrm{C}\right.$ in 
air). Theoretical ceramic yield calculated for $\mathrm{CaAl}_{2} \mathrm{O}_{4}: 29.6 \%$.

\section{Strontium aluminate precursor \\ $\left(\mathrm{SrAl}_{2} \mathrm{C}_{18} \mathrm{H}_{37} \mathrm{O}_{9} \mathbf{N}_{3}\right)$}

Aluminium hydroxide hydrate $(3.52 \mathrm{~g}$, $19.1 \mathrm{mmol}$ of $\left.\mathrm{Al}_{2} \mathrm{O}_{3}\right), \mathrm{Sr}(\mathrm{OH})_{2} \cdot 8 \mathrm{H}_{2} \mathrm{O}(5.01 \mathrm{~g}$, $18.9 \mathrm{mmol})$, and TEA $(8.61 \mathrm{~g}, 57.7 \mathrm{mmol})$ were mixed and heated with $200 \mathrm{ml}$ of EG in a $250 \mathrm{ml}$ flask. The reaction cleared in about $30 \mathrm{~min}$ and EG was distilled out along with by-product water until the solution had been concentrated to about $50 \mathrm{ml}$. Then the solvent was vacuum-dried at $150{ }^{\circ} \mathrm{C}$ for $12 \mathrm{~h}$, to yield a white solid. Yield: $9.15 \mathrm{~g}(98.2 \%)$. The solid was dissolved in THF, and rapidly reprecipitated in hexane, vacuumdried at $100{ }^{\circ} \mathrm{C}$ for $6 \mathrm{~h}$ and then subjected to analyses. TGA ceramic yield $33.2 \%\left(950{ }^{\circ} \mathrm{C}\right.$ in air). Theoretical ceramic yield calculated for $\mathrm{SrAl}_{2} \mathrm{O}_{4}: 35.4 \%$. Elemental analysis (\%): Found (calculated): C, 37.0 (37.2); H, 6.7 (6.4); N, 6.9 (7.2).

\section{Thermogravimetric analysis (TGA)}

TGAs were performed using a 2950 Thermal Analysis Instrument (TA Instruments, Inc., New Castle, DE, USA). Samples (10-20 mg) were placed in a platinum pan and heated in flowing, dry air $\left(60 \mathrm{~cm}^{3} \mathrm{~min}^{-1}\right)$, in 'Hi-Res 4.0 mode' at $50{ }^{\circ} \mathrm{C} \min ^{-1}$ to $1000{ }^{\circ} \mathrm{C}$.

\section{NMR spectroscopy}

NMR spectra were recorded using a Bruker Aspect 3000, AM-360 MHz spectrometer (Bruker Instruments Inc., Manning Park, Billerica, MA, USA). ${ }^{29} \mathrm{Si}\left\{{ }^{1} \mathrm{H}\right\}$ NMR spectra were obtained with the spectrometer operating at $59.6 \mathrm{MHz}$ and using a $32000 \mathrm{~Hz}$ spectral width, a relaxation delay of $15 \mathrm{~s}$, a pulse width of $58^{\circ}$, and 32000 data points. The samples were dissolved in distilled EG. $\mathrm{C}_{6} \mathrm{D}_{6}$ and tetramethylsilane, in a sealed inner tube, served as lock and reference materials, respectively. ${ }^{27} \mathrm{Al}$ NMR spectra were obtained with the spectrometer operating at $93.8 \mathrm{MHz}$ and using a $41000 \mathrm{~Hz}$ spectral width, a relaxation delay of $0.2 \mathrm{~s}$ and a pulse width of $13^{\circ}$. The samples were dissolved in distilled EG. $\mathrm{D}_{2} \mathrm{O}$ in a sealed inner tube served as the lock solvent and a $1 \mathrm{M}$ solution of $\mathrm{AlCl}_{3}$ in $\mathrm{D}_{2} \mathrm{O} / \mathrm{H}_{2} \mathrm{O}(1: 1)$ served as the external reference. ${ }^{1} \mathrm{H}$ and ${ }^{13} \mathrm{C}$ spectra were taken with the samples dissolved in $\mathrm{CDCl}_{3}$.

\section{Mass spectroscopy}

Mass spectra of the samples were recorded at the University of Michigan, Department of Chemistry. FAB studies were conducted using a VG 70-70-E, a magnetic-sector, double-focusing mass spectrometer made by VG Analytical; the spectrometer is operated using the 11-250-J data collection software system supplied with it.

The spectrometer was scanned from $\mathrm{m} / z 2800$ to $m / z 75$, using an exponential-down magnet scan and an external calibration against CsI clusters. The sample was dissolved in 3-nitrobenzyl alcohol and deposited on the target, on the probe tip. Prominent matrix (3-nitrobenzyl alcohol) peaks were subtracted out. Low-intensity peaks were the average of 10 or more scans, averaged as continuum data. The continuum data were then smoothed and centroided by the data system. The FAB gun used xenon gas, and was run at $1 \mathrm{~mA}$ current and $10 \mathrm{kV}$.

\section{Pyrolysis studies}

Samples (approx. $1 \mathrm{~g}$ ) of all three aluminate precursors were placed in separate alumina boats and heated in dry air at $10^{\circ} \mathrm{C} \mathrm{min}{ }^{-1}$ to $300{ }^{\circ} \mathrm{C}$; this was followed by a $2 \mathrm{~h}$ hold in a Thermolyne Type 6000 Furnace in flowing air $\left(100 \mathrm{ml} \mathrm{min}^{-1}\right)$, equipped with a Eurotherm programmable temperature controller (Model No. 818P, Northing, UK). Then the samples were transferred to a 51314 Lindberg furnace equipped with a Lindberg 59246-P Com controller, and heated in flowing air to $1200{ }^{\circ} \mathrm{C}$ at $40{ }^{\circ} \mathrm{C} \mathrm{min}{ }^{-1}$, with 1 and $2 \mathrm{~h}$ holds at $300{ }^{\circ} \mathrm{C}$ and $500{ }^{\circ} \mathrm{C}$ respectively.

\section{$X$-ray diffraction (XRD) studies of precursor pyrolysis products}

Samples (40-80 mg) were loaded in sample holders (glass plates) and a Rigaku rotating anode goniometer (Regaku Denki Co. Ltd, Tokyo, Japan) was used for data collection. The working voltage and current were $40 \mathrm{kV}$ and $100 \mathrm{~mA}$ respectively. $\mathrm{Cu} \mathrm{K} \alpha(\lambda=1.54 \AA)$ radiation with a nickel filter was used. Scans were continuous in the range $2 \theta=5-80^{\circ}$ with a step scan of $2 \theta=10^{\circ} \mathrm{min}^{-1}$ and increments of $2 \theta=0.05^{\circ}$. Products (peak positions and relative intensities) were characterized by comparison with standard JCPDS files. 


\section{RESULTS AND DISCUSSION}

The precursors were made from inexpensive starting materials in high yields. Both routes (stepwise and one-pot) provide the same precursors, as was proved by thermogravimetric and mass spectral analyses. Only the stepwise route product is analysed in detail here to establish the molecular structure of the precursor. The precursors are soluble in common organic solvents and in EG, except for the barium aluminate precursor, which precipitates out during the synthesis (see the Experimental section) and is insoluble in any solvent. However, it is soluble enough in $\mathrm{CDCl}_{3}$ and EG to obtain satisfactory ${ }^{1} \mathrm{H}$ and ${ }^{13} \mathrm{C}$, and ${ }^{27} \mathrm{Al}$, NMR spectra respectively. The decreased solubility of the barium aluminate precursor is not unexpected, based on the proposed structure, as the solubility of these precursors is believed to be due to the encapsulation of the metal ion by bridging TEA. The larger $\mathrm{Ba}^{2+}$ ion may not fit into the TEA cavity. Efforts to synthesize related double alkoxide complexes with a bridging glycolato ligand, instead of bridging TEA, always lead to EG insoluble precipitates (R. Narayanan and R. M. Laine, unpublished results). This supports the idea that the TEA encapsulation (see Eqn [4]) is required for solubility.

Analyses of the precursors and characterization of precursor structure by various techniques are discussed below.

\section{TGA}

The TGA profiles can be used to develop a pyrolysis protocol to transform precursors to carbon-free inorganic materials in minimum times and at minimum temperatures, and to confirm the composition of the proposed precursor. The TGA decomposition profiles (Figs 1-3) of all three precursors are similar and have three major mass-loss regions. The first major mass loss occurs below $400{ }^{\circ} \mathrm{C}$ and corresponds to ligand decomposition, the second from 400 to $600{ }^{\circ} \mathrm{C}$ to oxidation of organic char produced by ligand decomposition, and the third one between 800 and $950{ }^{\circ} \mathrm{C}$ to carbonate decomposition. The proposed mechanisms for the decomposition processes are discussed elsewhere. ${ }^{21}$ No excess solvent or solvent of recrystallization is seen in any case and the ceramic yields observed in TGA match (within $0.4-0.8 \%$ ) those calculated from the proposed precursor structure in all three

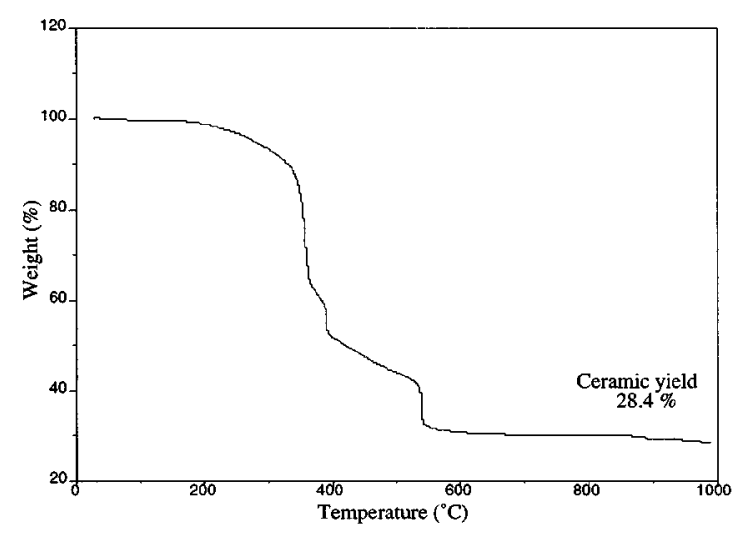

Figure 1 TGA of $\mathrm{CaAl}_{2} \mathrm{C}_{18} \mathrm{H}_{37} \mathrm{O}_{9} \mathrm{~N}_{3}$ precursor in air.

'stepwise synthesis' precursors. The ceramic yields of the precursors made by one-pot synthesis are lower by $2.5-3 \%$, because a slight excess of TEA is used and it is difficult to remove by vacuum evaporation. ${ }^{19}$ The ceramic yields, along with the elemental analyses, confirm the compo-

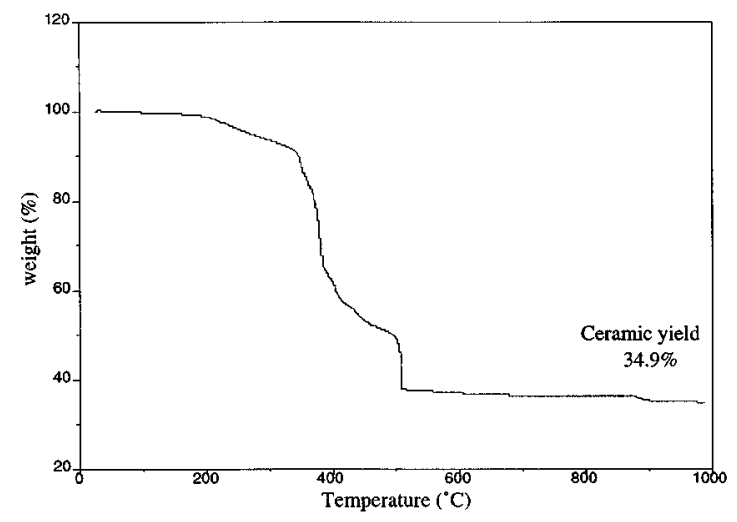

Figure 2 TGA of $\mathrm{SrAl}_{2} \mathrm{C}_{18} \mathrm{H}_{37} \mathrm{O}_{9} \mathrm{~N}_{3}$ precursor in air.

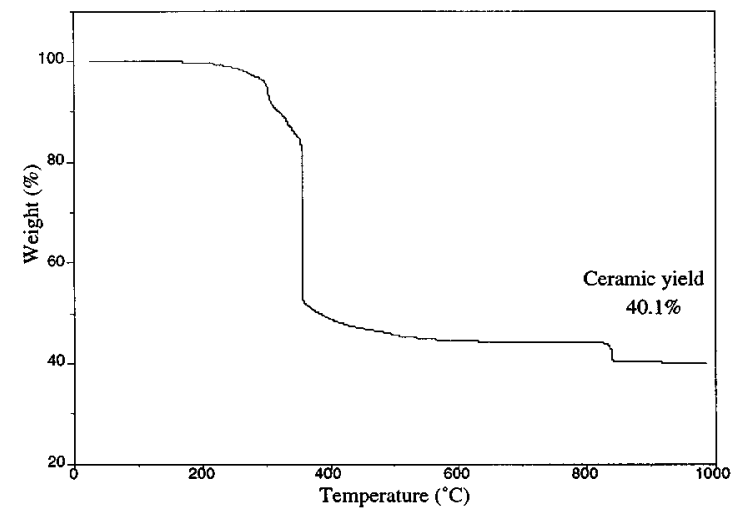

Figure 3 TGA of $\mathrm{BaAl}_{2} \mathrm{C}_{18} \mathrm{H}_{37} \mathrm{O}_{9} \mathrm{~N}_{3}$ precursor in air. 
sition of the structure proposed for the precursors in the reaction of Eqn [4] above.

\section{NMR}

The ${ }^{1} \mathrm{H}$ and ${ }^{13} \mathrm{C}$ NMR values for the precursors, along with their tentative assignments, are listed in Table 1. The presence of quadrupolar nuclei (Al and $\mathrm{N}$ ) broaden the peaks, thus obscuring their multiplicity in ${ }^{1} \mathrm{H}$ NMR and making the ${ }^{13} \mathrm{C}$ NMR less informative. Furthermore, the three ethyleneoxy 'arms' in the central bridging TEA may exchange on the NMR timescale, which could also lead to peak broadening. The free ethyleneoxy group among the three 'arms' of the bridging TEA is not discernible by either ${ }^{1} \mathrm{H}$ or ${ }^{13} \mathrm{C}$ NMR. However, the chemical shift values are in agreement with standard, predicted values and also similar to those reported for the spinel precursor. $^{19}$

The ${ }^{27} \mathrm{Al}$ NMR spectrum has only one broad peak, indicative of a tetracoordinated $\mathrm{Al},{ }^{22-24}$ in all three precursors (Table 1). In contrast, alumatrane exhibits two broader (than the aluminates) peaks, corresponding to hexa- and tetra-coordinate $\mathrm{Al}$, as expected from the asymmetric tetrameric structure reported. ${ }^{25}$ The tetramer results from the dative bonds between the aluminium of one alumatrane and oxygens on three other alumatranes. ${ }^{25}$ The quadrupole moment then of ${ }^{27} \mathrm{Al}$ nucleus causes considerable dependence of the signal width on the gradient of the electric field around the Al nucleus, i.e. on the geometrical arrangement of the substituents around the $\mathrm{Al}$ atom. ${ }^{22}$ In the Group II dialuminate precursors, the ${ }^{27} \mathrm{Al} \mathrm{NMR}$ peak is sharper than alumatrane, indicating a more symmetrical envi- ronment, as in the trimetallic double alkoxide structure proposed in reaction [4]. The chemical shift values (around $62 \mathrm{ppm}$ ) are typical of tetracoordinate $\mathrm{Al}^{22-24}$ suggesting that the dative bonds seen in alumatrane no longer exist.

\section{Mass spectroscopy}

Fast atom bombardment (FAB) mass spectral analysis is the only technique that can be used for complexes such as the aluminate precursors. FAB analysis requires that the samples be dispersed on a matrix. All three possible matrix solvents, i.e. TEA, glycerol and p-nitrobenzyl alcohol (NBA), interact with the precursors, as was found for the spinel and potassium aluminosilicate precursors. ${ }^{19,20}$ However, with NBA the peaks due to fragmentation of precursors can still be seen amidst matrix interaction peaks (Table $2)$. Both positive- and negative-ion FAB analyses were done and only the latter was found to be informative. The fragmentation patterns can be explained on the basis of the proposed precursor structure. Intensities of molecular peaks and matrix interaction peaks differ from sample to sample, but the fragmentation patterns for all three precursors are quite similar. A deprotonated molecular ion peak is seen as a significant peak in all three cases. The isotope distributions for the molecular ion peak in all three precursors agree reasonably with those calculated using an 'Isotope pattern calculator' (see Table 3). No evidence is found for higher molecular weight species that might arise by disproportionation or exchange reactions that are common in aluminium alkoxides. ${ }^{26}$ However, low-intensity

Table 1 NMR data for TEA-Al-TEA-Al-TEA M precursors

\begin{tabular}{|c|c|c|c|}
\hline $\begin{array}{l}\mathrm{MAl}_{2} \mathrm{C}_{18} \mathrm{H}_{37} \mathrm{O}_{9} \mathrm{~N}_{3} \\
\text { precursor }\end{array}$ & ${ }^{1} \mathrm{H}$ NMR & ${ }^{13} \mathrm{C} \mathrm{NMR}$ & ${ }^{27} \mathrm{Al} \mathrm{NMR}$ \\
\hline $\mathrm{M}=\mathrm{Ca}$ & $\begin{array}{l}2.7(\mathrm{~b}),\left(\mathrm{NCH}_{2}\right), 3.7(\mathrm{~b}), \\
\left(\mathrm{AlOC} \underline{\mathrm{H}}_{2}\right) ; \text { equal intensities, } \\
\text { shoulder peaks (free } \\
\text { ethyleneoxy?) }\end{array}$ & $\begin{array}{l}53.2\left(\mathrm{NCH}_{2} \mathrm{CH}_{2} \mathrm{OAl}\right), 56.3 \\
\left(\mathrm{NCH}_{2} \mathrm{CH}_{2} \mathrm{OH}\right), 57.5\left(\mathrm{AlOCH}_{2}\right), \\
58.0\left(\mathrm{NCH}_{2} \underline{\mathrm{CH}} \mathrm{H}_{2} \mathrm{OH}\right.\end{array}$ & 62.9 (tetracoordinate) \\
\hline $\mathrm{M}=\mathrm{Sr}$ & $\begin{array}{l}2.7(\mathrm{~b}),\left(\mathrm{NCH}_{2}\right), 3.7(\mathrm{~b}), \\
\left(\mathrm{AlOC} \underline{\mathrm{H}}_{2}\right) ; \text { equal intensities, } \\
\text { shoulder peaks (free } \\
\text { ethyleneoxy?) }\end{array}$ & $\begin{array}{l}53.1\left(\mathrm{NCH}_{2} \mathrm{CH}_{2} \mathrm{OAl}\right), 54.1 \\
\left(\mathrm{NC}_{2} \mathrm{CH}_{2} \mathrm{OH}\right), 57.5\left(\mathrm{AlOC} \mathrm{H}_{2}\right), \\
59.7\left(\mathrm{NCH}_{2} \underline{C H}_{2} \mathrm{OH}\right)\end{array}$ & 62.7 (tetracoordinate) \\
\hline $\mathrm{M}=\mathrm{Ba}$ & $\begin{array}{l}2.7(\mathrm{~b}),\left(\mathrm{NCH}_{2}\right), 3.7(\mathrm{~b}), \\
\left(\mathrm{AlOC} \underline{\mathrm{H}}_{2}\right) ; \text { equal intensities, } \\
\text { shoulder peaks (free } \\
\text { ethyleneoxy?) }\end{array}$ & $\begin{array}{l}53.0\left(\mathrm{NCH}_{2} \mathrm{CH}_{2} \mathrm{OAl}\right), 56.2 \\
\left(\mathrm{NC}_{2} \mathrm{CH}_{2} \mathrm{OH}\right), 57.6\left(\mathrm{AlOCH}_{2}\right), \\
58.9\left(\mathrm{NCH}_{2} \underline{C H}_{2} \mathrm{OH}\right)\end{array}$ & 62.6 (tetracoordinate) \\
\hline
\end{tabular}


Table 2 Mass spectral analyses ${ }^{\mathrm{a}}$ of TEA-Al-TEA-Al-TEA M

\begin{tabular}{|c|c|c|c|}
\hline & $\mathrm{M}=\mathrm{Ca}$ & $\mathrm{M}=\mathrm{Sr}$ & $\mathrm{M}=\mathrm{Ba}$ \\
\hline Fragment assigned & $\mathrm{m} / \mathrm{z}$ Intensity & $\mathrm{m} / \mathrm{z}$ Intensity & $\mathrm{m} / \mathrm{z}$ Intensity \\
\hline$(\mathrm{TEA}-\mathrm{Al})_{2} \mathrm{TEA}-\mathrm{M}-\mathrm{H}^{+}$ & 53297.6 & $580 \quad 72.4$ & $630 \quad 20.5$ \\
\hline TEA-Al-O- $-\mathrm{CH}_{2}-\mathrm{C}_{6} \mathrm{H}_{4}-\mathrm{NO}_{2}$ & 32585.2 & 325100.0 & 325100.0 \\
\hline$(\mathrm{TEA}-\mathrm{Al})_{2} \mathrm{TEA}-\mathrm{M}+\mathrm{O}-\mathrm{CH}_{2}-\mathrm{C}_{6} \mathrm{H}_{4}-\mathrm{NO}_{2}$ & $686 \quad 42.5$ & $734 \quad 76.0$ & $784 \quad 76.0$ \\
\hline$(\mathrm{TEA}-\mathrm{Al})_{2} \mathrm{TEA}-\mathrm{M}-\mathrm{H}^{+}+\mathrm{TEA}-\mathrm{Al}$ & 705100.0 & $753 \quad 5.6$ & - - \\
\hline$\left[(\mathrm{TEA}-\mathrm{Al})_{2} \mathrm{TEA}-\mathrm{M}+2\left(\mathrm{HO}-\mathrm{CH}_{2}-\mathrm{C}_{6} \mathrm{H}_{4}-\mathrm{NO}_{2}\right)\right]-\mathrm{H}^{+}$ & $839 \quad 3.2$ & 887 & $937 \quad 2.4$ \\
\hline$\left[(\mathrm{TEA}-\mathrm{Al})_{2} \mathrm{TEA}-\mathrm{M}\right]_{2}$ & 1066 & 1162 & $-\quad-$ \\
\hline
\end{tabular}

${ }^{a}$ Matrix, p-nitrobenzyl alcohol. Method, negative-ion FAB.

(approx. 2\%) dimer peaks were seen, which might arise by hydrogen bonding.

\section{Pyrolysis studies}

A two-stage bulk pyrolysis process, developed for the spinel precursor based on the TGA profile, ${ }^{19}$ was used to pyrolyse these precursors. The precursors were pyrolysed to $1200{ }^{\circ} \mathrm{C}$, where crystallization is complete in the spinel precursor. ${ }^{19}$ Strontium and barium aluminate precursors transform to the corresponding phasepure aluminates (Fig. 4). Pyrolysis of calcium aluminate precursor results in a mixture of $\mathrm{CaAl}_{2} \mathrm{O}_{4}, \mathrm{CaAl}_{4} \mathrm{O}_{7}$ and $\mathrm{CaO}$ phases. However, it is known that variations in the pyrolysis time and temperature greatly affect the phase distribution in calcium aluminates. ${ }^{16}$ Thus the formation of mixed phases as seen here is not uncommon.

Table 3 Isotope pattern analyses of the molecular ion peaks of $\mathrm{MAl}_{2} \mathrm{O}_{4}$ precursors

\begin{tabular}{|c|c|c|c|c|c|c|}
\hline \multirow[b]{3}{*}{ Element } & \multicolumn{6}{|c|}{ Intensity $^{\mathrm{a}}$} \\
\hline & \multicolumn{2}{|c|}{$M+1$} & \multicolumn{2}{|c|}{$M+2$} & \multicolumn{2}{|c|}{$M-1$} \\
\hline & Obs. & Calcd & Obs. & Calcd & Obs. & Calcd \\
\hline $\mathrm{Ca}$ & 21.2 & 22.1 & 5.66 & 4.8 & - & - \\
\hline $\mathrm{Sr}$ & 20.0 & 22.1 & 5.60 & 4.1 & - & - \\
\hline $\mathrm{Ba}$ & 24.9 & 22.1 & - & - & 20.9 & 17.8 \\
\hline
\end{tabular}

${ }^{a}$ Molecular ion peak intensity was taken as $100 \%$ in each case, for calculations.

\section{CONCLUSIONS}

Low-cost Group II metal aluminate precursors are efficiently synthesized using a simple, general process starting from $\mathrm{Al}(\mathrm{OH})_{3}$, metal oxides/hydroxides, EG and TEA. As the precursors are soluble in common organic solvents, the processability of these precursors into different shapes and forms (films, fibres, coatings etc.) should be possible. The analyses of the precursors suggest an 'ionomer-like' structure, in which two alumatrane units are bridged by a TEA moiety and the bridging TEA encapsulates the Group II metal ion (see reaction [4]). Only determination of crystal structure will constitute a direct proof for the 'metal-encapsulating TEA' proposed in the structure. To date, efforts to grow crystals have been unsuccessful. However, other analyses prove the composition of the precursor beyond doubt and the decreasing solubility with increasing metal ion size, as seen in the case of $\mathrm{Ba}$, suggests the proposed metal-encapsulated structure for the given composition.

In any molecular ceramic precursor, homogeneous cation distribution and stoichiometry at the molecular level are necessary conditions to produce a homogeneous ceramic material. ${ }^{13}$ In our precursors, stoichiometric control at the molecular level has been achieved as seen in the precursor structure. Understanding the chemistry of the precursors enables us to appreciate and utilize the generality of the technique. This aspect of the OOPS process sets it apart from any existent solution processing techniques and it is expected to be widely used for the production of a variety of mixed-cation oxide materials. 


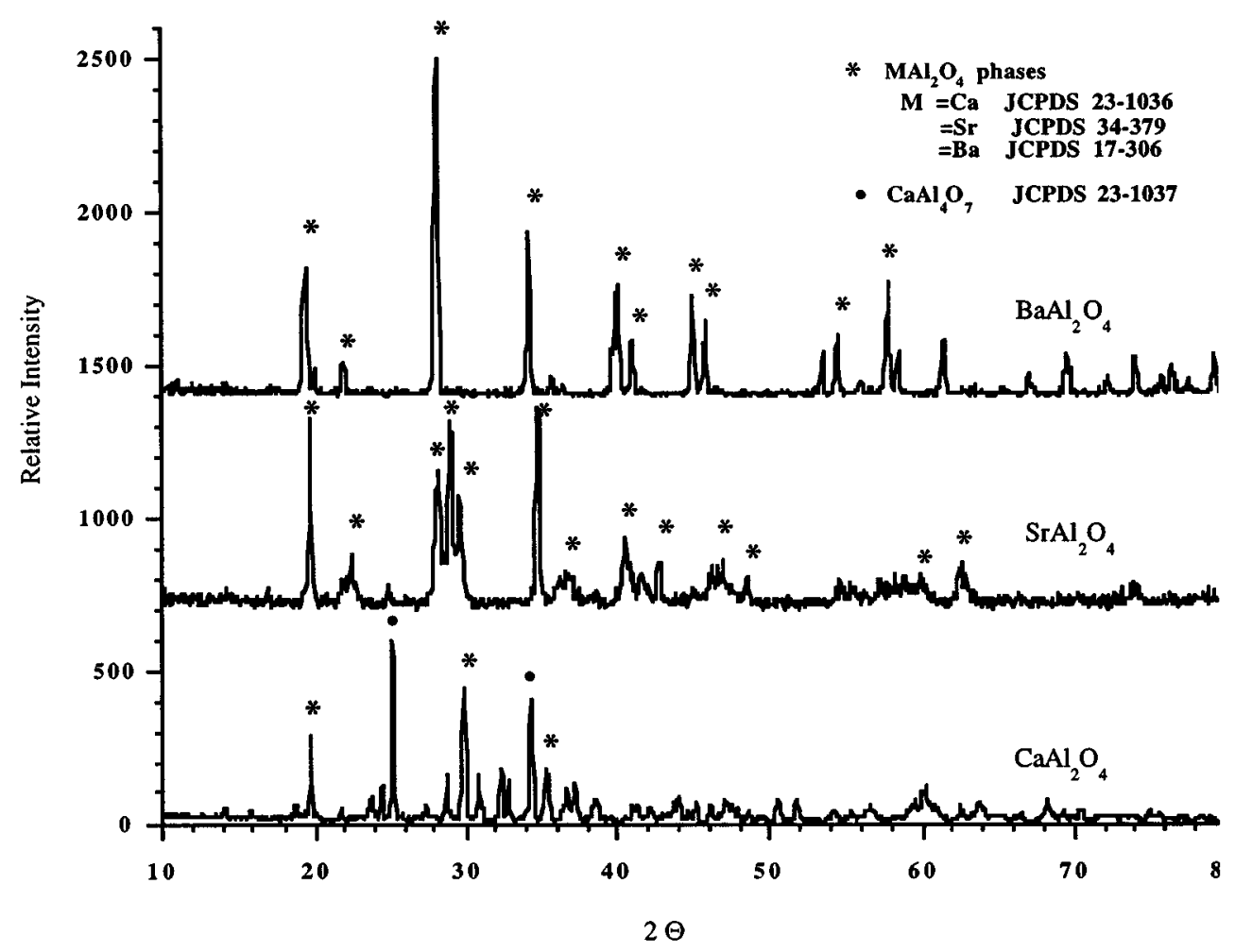

Figure 4 XRD of $\mathrm{MAl}_{2} \mathrm{C}_{18} \mathrm{H}_{37} \mathrm{O}_{9} \mathrm{~N}_{3}$ precursors pyrolysed to $1200{ }^{\circ} \mathrm{C}$.

Acknowledgements We thank the Federal Aviation Administration for support of this work through grant no. 95-G-026. We would also like to thank the Army Research Office for partial support of this work through the grant DAAH04/95-1-0407.

\section{REFERENCES}

1. A. G. Holterhoff, Am. Ceram. Soc. Bull. 75, 113 (1996).

2. J. D. Birchall, A. J. Howard and K. Kendall, Nature (London) 289, 388 (1981).

3. A. I. Kingdon, R. F. Davis and M. M. Thackery, Introduction to Glasses and Ceramics, Vol. 4, ASM International, Materials Park, OH, 1991, p. 765.

4. S. Sharafat, N. M. Ghoniem, P. I. H. Cooke, R. C. Martin, F. Najmabadi, K. R. Schultz and C. P. C. Wong, Fusion Engng. Design 23, 99 (1993).

5. A. S. Escribano, M. Primet and H. Praliaud, Appl. Catal. A 108, 221 (1994)

6. B. Smets, J. Rutten, G. Hoeks and J. Verlijsdonk, J. Electrochem. Soc. 136(7), 2119 (1989).

7. K. Fuji, W. Kondo and H. Ueno, J. Am. Ceram. Soc. 69(4), 361 (1986).

8. C. J. Brinker and G. W. Scherer, Sol-Gel Science: The
Physics and Chemistry of Sol-Gel Processing, Academic Press, Boston, MA, 1990.

9. (a) D. Lepkova, A. Batarjav, B. Samuneva, Y. Ivanova and L. Georgieva, J. Mater. Sci. 26, 4861 (1991); (b) G. Gusmano, P. Nunziante, E. Traversa and G. Chiozzini, J. Eur. Ceram. Soc. 7, 31 (1991).

10. P. A. Lessing, Am. Ceram. Soc. Bull. 68(5), 1002 (1989).

11. N. G. Eror and H. U. Anderson, in : Better Ceramics Through Chemistry II, Brinker, C. J., Clark, D. E. and Ulrich, D. R. (eds), Mater. Res. Soc. Symp. Proc. Vol. 73, Materials Research Society, Pittsburgh, PA, 1986, pp. 571-577.

12. L. W. Tai and P. A. Lessing, J. Mater. Res. 7(2), 502 (1992).

13. S. C. Zhang, G. L. Messing, W. Huebner and M. M. Coleman, J. Mater. Res. 5(9), 1806 (1990).

14. S. G. Cho, P. F. Johnson and R. A. Condrate Sr, J. Mater. Sci. 25, 4738 (1990).

15. P. G. Desai, Z. Xu and J. A. Lewis, J. Am. Ceram. Soc. 78(11), 2881 (1995).

16. M. A. Gulgun, O. O. Popoola and W. M. Kriven, J. Am. Ceram. Soc. 77(2), 531 (1994).

17. M. Uberoi and S. H. Risbud, J. Am. Ceram. Soc. 73(6), 1768 (1990).

18. R. M. Laine, D. R. Treadwell, B. L. Mueller, C. R. Bickmore, K. F. Waldner and T. Hinklin, J. Mater. Chem. 6, 1441 (1996). 
19. K. F. Waldner, R. M. Laine, S. Dhumrongvaraporn, S. Tayaniphan and R. Narayanan, Chem. Mater. 8(12), 2850 (1996).

20. R. Narayanan and R. M. Laine, in: Proc. Symp. Hightemperature Synthesis of Materials, ACS National Meeting, Orlando, FL, 25-29 Aug. 1996, in press.

21. R. Baranwal and R. M. Laine, J. Am. Ceram. Soc., 80(6), 1436 (1997).

22. O. Kriz, B. Casensky, A. Lycka, J. Fusek and S. Hermanek, J. Magn. Res. 60, 375 (1984).

23. C. Gerardin, S. Sundaresan, J. Benziger and A.
Navrotsky, Chem. Mater. 6, 160 (1994).

24. J. W. Akitt, Multinuclear studies of aluminum compounds. In: Progress in NMR Spectroscopy, Pergamon, New York, 1989, pp. 1-149.

25. (a) V. E. Shklover, Yu. Struchkov, M. G. Voronkov, Z. A. Ovchinnikova and V. P. Baryshok, Dokl. Akad. Nauk SSR 227, 1185 (1984); Chem. Abstr. 102, 37181k (1984); (b) M. G. Voronkov and V. P. Baryshok, J. Organomet. Chem. 239, 199 (1982).

26. R. C. Mehrotra and A. K. Kai, Polyhedron 10, 1967 (1991). 